\title{
Methanol contamination in traditionally fermented alcoholic beverages: the microbial dimension
}

\author{
Elijah Ige Ohimain*
}

\begin{abstract}
Incidence of methanol contamination of traditionally fermented beverages is increasing globally resulting in the death of several persons. The source of methanol contamination has not been clearly established in most countries. While there were speculations that unscrupulous vendors might have deliberately spiked the beverages with methanol, it is more likely that the methanol might have been produced by contaminating microbes during traditional ethanol fermentation, which is often inoculated spontaneously by mixed microbes, with a potential to produce mixed alcohols. Methanol production in traditionally fermented beverages can be linked to the activities of pectinase producing yeast, fungi and bacteria. This study assessed some traditional fermented beverages and found that some beverages are prone to methanol contamination including cachaca, cholai, agave, arak, plum and grape wines. Possible microbial role in the production of methanol and other volatile congeners in these fermented beverages were discussed. The study concluded by suggesting that contaminated alcoholic beverages be converted for fuel use rather than out rightly banning the age-long traditional alcohol fermentation.
\end{abstract}

Keywords: Traditional fermentation, Indigenous fermentation, Pectin, Pectin methyl esterase, Toxic ethanol, Methanol, Volatile congeners, Raffia palm

\section{Background}

Beverage ethanol production via fermentation is an age long tradition in many parts of the world. In the tropical world and elsewhere, indigenous people are involved in the entire value chain of traditional alcohol fermentation. Jespersen (2003) reported that most beverages and foods in Africa are produced at household level or on small industrial scale often of varying qualities. Aiyeloga et al. (2014) reported the potentials of raffia palm wine in sustaining livelihood in rural and urban populations in Nigeria. However, in Africa, Asia and South America, there has been an increasing incidence of methanol contamination in traditionally fermented alcoholic drinks (WHO 2014). Several cases of methanol poisoning have been reported in India and elsewhere. For instance in 2008, over 180 persons were killed in Bangalore and in

*Correspondence: eohimain@yahoo.com

Ecotoxicology Research Group, Biological Sciences Department, Niger Delta University Wilberforce Island, Amassoma, Bayelsa State, Nigeria
2009, 138 were killed in Gujarat, India. In 2015, 27 persons died in India after consuming toxic ethanol. In 2009, 25 persons died in Indonesia after consuming fermented palm wine containing methanol. About 130 persons died in some India villages in 2011 linked to poisonous ethanol consumption. In Czech Republic, 127 persons were poisoned from contaminated alcohol, out of which 42 died (Vaskova 2013). In 2014, the World Health Organization (WHO) alerted that there have been increasing outbreaks of methanol poisoning in several countries including Kenya, Gambia, Libya, Uganda, India, Ecuador, Indonesia, Nicaragina, Pakistan, Turkey, Czech Republic, Estonia and Norway. The size of these outbreaks ranged from 20 to over 800 victims, with case fatality rates of over $30 \%$ in some cases (WHO 2014). Lachenmeier et al. (2011) evaluated the risk of contaminated unregulated alcohol in the European Union.

In Nigeria, between April and June 2015, a total of 89 persons died following the consumption of locally produced ethanol beverage called kaikai/ogogoro/apeteshi 
or illicit gin. Kaikai is produced mostly from the sap of raffia palm and oil palm and to a lesser extent from other palms such as date palm, nipa palm etc. Laboratory analysis carried out by WHO and NAFDAC (National Agency for Food, Drug Administration and Control) show that the beverage contain $16.3 \%$ methanol, while the blood methanol concentration of victims was found to be $1500-2000 \mathrm{mg} / \mathrm{l}$. Victims exhibited symptoms of methanol poisoning including loss of consciousness, dizziness, weakness and breathing difficulties, blurred vision and blindness, weight loss, headache, abdominal pains, nausea, diarrhea and vomiting (Methanol Institute 2013). WHO (2014) reported that blood methanol concentration above $500 \mathrm{mg} / \mathrm{l}$ is associated with severe toxicity, whereas concentration above $1500-2000 \mathrm{mg} / \mathrm{l}$ causes death in untreated victims. While investigation is ongoing on the source/origin of methanol in the beverage, the Federal Government of Nigeria (FGN) placed a ban on the production, sale, distribution and consumption of locally fermented beverage in Nigeria. Enforcement of the ban was heightened in the months (June-August 2015) following the incidence, but as of the time of writing (November 2015) enforcement has slacked. But the ban on the age long fermentation processes could have major impacts on the local economy. For instance, over 50 million people consume palm wine in Southern Nigeria (Obahiagbon 2009).

Raffia palm, which is among the most diverse and geographically widespread palm, is found in Africa, Asia and South America (Oduah and Ohimain 2015). The palm has many potential uses (Oduah and Ohimain 2015) but it is currently undertilized (Ohimain et al. 2015). Production of beverage ethanol from raffia palm provide a source of employment especially for rural people (Obahiagbon and Osagie 2007; Ohimain et al. 2012). Aiyeloja et al. (2014) studied the potential of raffia palm in the sustenance of rural and urban population in Nigeria. They found that raffia palm beverage value chain provides profit of 50,000- $\$ 90,000$ (\$ $1=$ 220) to producers and $45,000-\$ 70,000$ to marketers. The complete ban on traditionally fermented beverages could be detrimental to the country's economy especially at a time when most economics are under recession, with high inflation and un-employment rates. Nigeria is currently experiencing an economic downturn due to low crude oil prices. Hence, there is the need to establish the source/cause of methanol in traditionally fermented alcoholic beverages. Methanol Institute (2013) reported that methanol is often deliberately added to alcoholic beverages by unscrupulous and illegal criminal enterprises as a cheaper alternative to the production of cheaper ethanol. This may be unlikely in Nigeria and many other developing countries where methanol is not domestically produced but imported at costs higher than the cost of alcoholic beverage. For instance, domestically produced ethanol (40-60\% alcohol content) is quite cheap costing 20 per shot of $30 \mathrm{ml}$ i.e. $\$ 670 / 1$ as against $\$ 5168 / 1$ of $99.85 \%$ methanol (excluding importation and duty costs). Hence, there is need for research to focus on other possible sources of methanol in locally fermented beverages. WHO (2014) reported that outbreaks of methanol often occur when methanol is added to alcoholic beverages. Ohimain et al. (2012) reported that alcoholic beverages are produced in Nigeria using rudimentary equipment under spontaneous fermentation, which lacked effective controls and are carried out by uneducated rural workers with poor hygiene in an unsterile environment. Traditional fermentation is carried out by mixed cultures consisting of yeast, other fungi and bacteria. Though, most of the traditionally fermented food and beverages are dominated by the yeast Saccharomyces cerevisiae, and to a lesser extent Lactobacillus (Jespersen 2003; Ogbulie et al. 2007; Karamoko et al. 2012; Rokosu and Nwisienyi 1980), the presence of other microbes can lead to the production of diverse products including methanol (Dato et al. 2005; Shale et al. 2013; Kostik et al. 2014). Several compounds could be produced during mixed fermentation with several organisms. Also, it has been severally reported that microbial fermentation of substrates rich in pectin can result in the formation of methanol (Nakagawa et al. 2000; Mendonca et al. 2011; Siragusa et al. 1988). Contaminating yeast has been demonstrated to produce methanol during traditional fermentation (Dato et al. 2005). Recent studies have also shown that the ethanol fermenting yeast, $S$. cerevisiae has several strains with slightly different metabolism (Jespersen 2003; Stringini et al. 2009; Okunowo et al. 2005) with some strains possibly producing methanol. More worrisome are recent studies showing increase in blood methanol level in some persons even after consumption of methanol-free ethanol (Shindyapina et al. 2014; Dorokhov et al. 2015). These authors recognized two sources of methanol in human systems, endogenous and exogenous sources. It is generally believed that unscrupulous vendors deliberately spike beverages with methanol in order to increase the alcohol content. The aim of this review is to present alternative viewpoint showing the possible role of microbes in the production of methanol in traditionally fermented beverages. We reviewed literatures on traditionally fermented alcoholic beverages, assessed the methanol content of the beverages, the pectin content of their feedstocks and the microbial species involved in the fermentation in an attempt to establish a possible role of microbes in the production of methanol in traditionally fermented alcoholic beverages. 


\section{Methanol contamination in fermented beverages}

The result of the review is presented in Table 1 , showing that several traditionally fermented alcoholic beverages in different countries could be prone to methanol contamination. Majority of the beverages are made from few feedstocks including palm wine, sorghum, millet, maize, sugarcane, citrus, banana, milk and Plum. Cases of methanol contamination have been reported in some of the wines produced from banana, plum and Agrave. Spirits made from mangoes, pears, banana and melon have been shown to contain methanol (Mendonca et al. 2011). In Rwanda, traces of methanol were reported in Urwagwa, a beer produced from banana (Shale et al. 2013). Mendonca et al. (2011) reported 0.05-0.189\% methanol in cachaca produced from banana pulp, while Dato et al. (2005) reported $0.00-0.50 \%$ methanol in cachaica produced from sugarcane in Brazil. Plum wine (Joshi et al. 2009; Jung et al. 2010), plum brandy (Kostik et al. 2014), agave (Leon-Rodriguez et al. 2008) contain methanol. The substrate for ethanol production is the first probable source of methanol in the beverage. Chaiyasut et al. (2013) reported factors affecting the methanol production in fermented beverages including raw material size and age, sterilization temperature, pectin content and pectin methyl esterase (PME) activity (Note that PME activity is optimal at $50-60{ }^{\circ} \mathrm{C}$ ).

Another possible source of methanol in traditionally fermented alcoholic beverage is the fermenting microbes. The ethanol fermenting yeast $S$. cerevisiae dominated traditional fermentation followed by Lactobacillus (Table 1). Jespersen (2003) also observed this trend in African indigenous fermented beverages and foods. Saccharomyces cerevisiae have been used as catalysts for the production of ethanol for thousands of years. But recent studies have shown that there are different strains of $S$. cerevisiae involved in traditional ethanol fermentation (Hayford and Jespersen 1999; Jespersen 2003; Kuhle et al. 2001; Pataro et al. 2000; Guerra et al. 2001; Ezeronye and Legras 2009). The big question is 'have the traditional ethanol producing yeast evolved into the production of methanol in addition'? Professor Benito Santiago, University of Spain (Personal communication, July 2015) opined that some years ago, methanol at low concentration was desirable in beer and wines. However, we were unable to find literature confirming this claim.

Pectins are a group of heterogeneous polysaccharides found in the intercellular regions and cell walls of most fruits and vegetables (Siragusa et al. 1988), with its greatest abundance in citrus particularly orange, grape, limes and lemons (Siragusa et al. 1988). Citrus contains 7-10\% pectin (Siragusa et al. 1988). Chaiyasut et al. (2013) compared pectin levels in fermented beverage containing Morinda citrifolia (9.89 \%) with that of other fruits including guava $(4.36 \%)$, tomato $(0.3 \%)$, apple $(0.5 \%)$, carrot $(0.8 \%)$ and cherries $(0.4 \%)$. During ripening, pectin in fruits is broken down by PME resulting in the formation of methanol (Chaiyasut et al. 2013; Micheli 2001). However, pectin has not been reported in palm wine.

Plant cell wall degrading enzymes including pectinases are ubiquitous among pathogenic and saprophytic bacteria and fungi (Prade et al. 1999). Pectin enzymes are widely distributed in nature and are produced by yeast, bacteria, fungi and plants (Sieiro et al. 2012). Methanol is a major end product of pectin metabolism by microorganisms (Schink and Zeikus 1980). Human colonic bacteria, Erwinia carotovora is able to degrade pectin releasing methanol (Siragusa et al. 1988). Anaerobic bacteria, particularly Clostridium butyricum, Clostridium thermocellum, Clostridium multifermentans, and Clostridium felsineum produce methanol from pectin (Ollivier and Garcia 1990). Schink and Zeikus (1980) reported various pectinolytic strains of Clostridium, Erwinia and Pseudomonas. Dorokhov et al. (2015) listed at least 20 species of human colonic microbes capable of producing methanol endogenously. The authors in a comprehensive review presented at least five different pathways of methanol synthesis in humans and four pathways of methanol clearance from the body and they also demonstrated the presence of gene regulation in methanol synthesis. Readers are advised to consult this literature for details on metabolic methanol in human systems.

Pectinolytic enzymes are classified into esterases and depolymerase (lyases and hydrolases). Hydrolysis of pectin by lyases produces oligo- or mono-galacturonate, while hydrolysis of pectin by esterases produces pectic acid and methanol (Sieiro et al. 2012). Some authors have identified strains of Saccharomyces that produces the three types of pectinolytic enzymes namely pectin methyl esterase (PME, EC: 3.1.1.11), pectin lyase (PL), and polygalacturonase (PG) (Gainvors et al. 1994a, b; Naumov et al. 2001). Fernandez-Gonzalez et al. (2005) genetically modified $S$. cerevisiae strain having pectinolytic activity. Analysis of $S$. cerevisiae among many traditional fermented beverages in Africa shows that they vary according to the location and types of substrates (Jespersen 2003). Strains of S. cerevisiae having PME activity could produce methanol during fermentation.

Methanol is produced during fermentation by the hydrolysis of naturally occurring pectin in the wort (Nakagawa et al. 2000; Mendonca et al. 2011). PME deesterify pectin to low-methoxyl pectins resulting in the production of methanol (Chaiyasut et al. 2013; Micheli 2001).

Jespersen (2003) reported the roles of S. cerevisiae in the traditional fermentation to include fermentation of carbohydrate to ethanol, production of aromatic and 


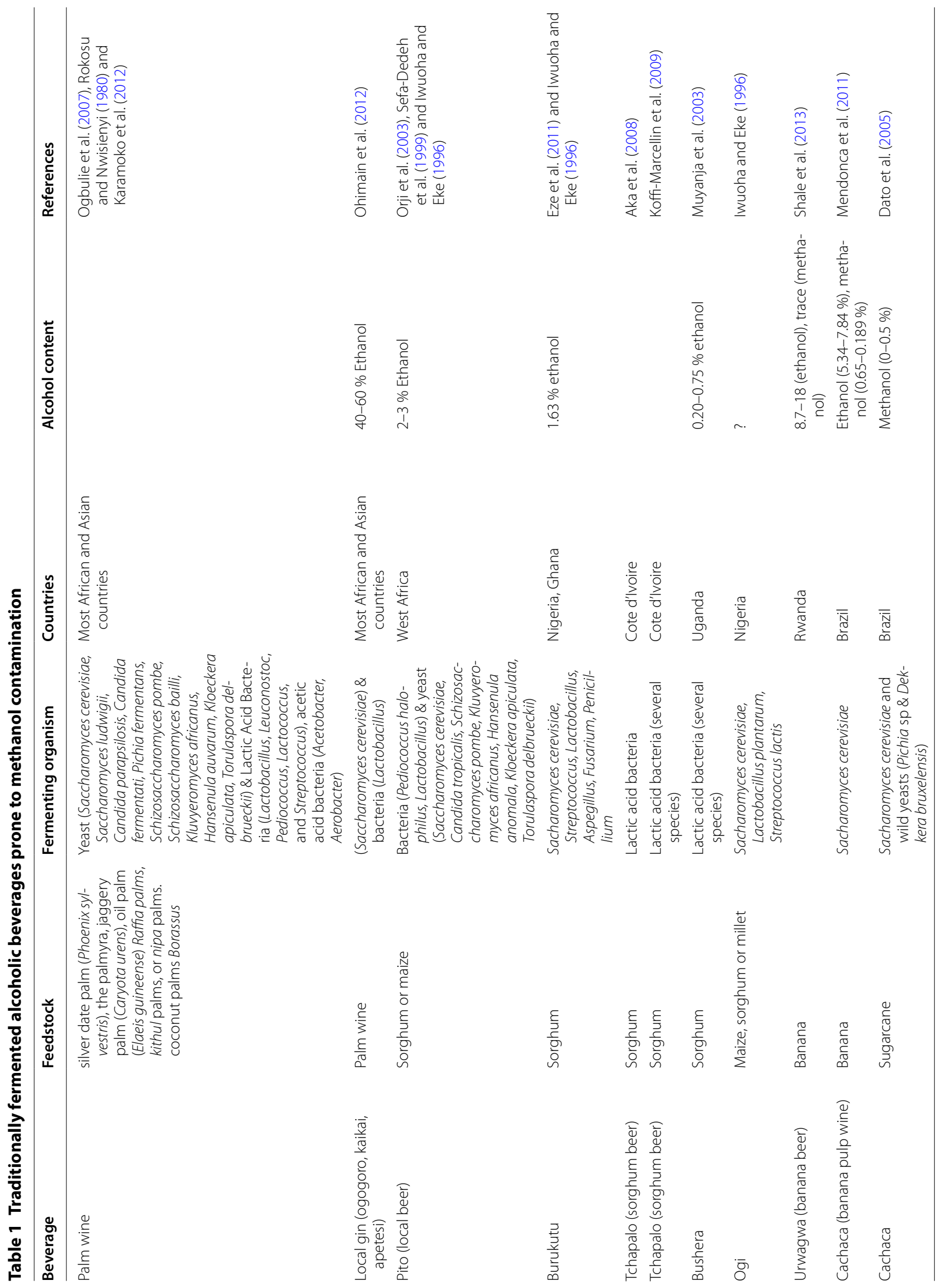




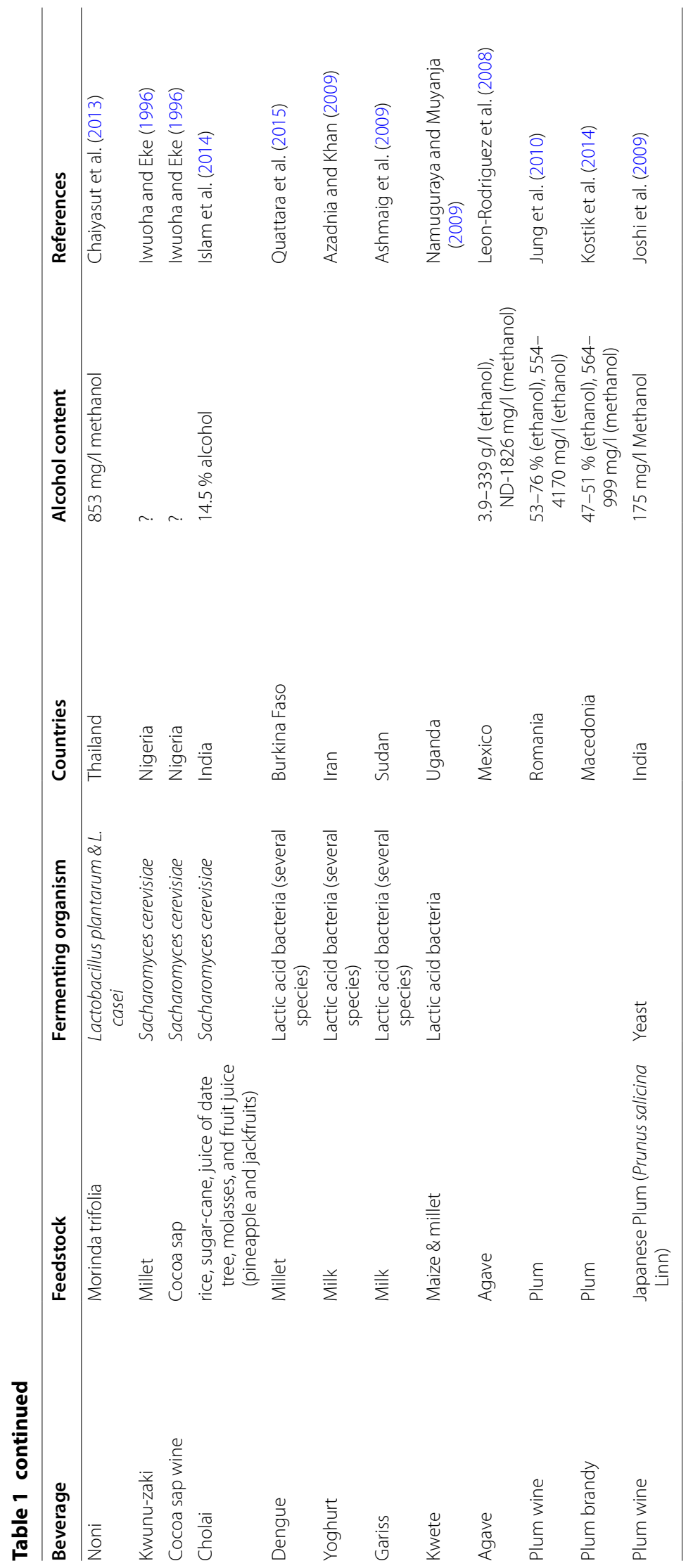


flavor compounds, stimulation of lactic acid bacteria and probiotic activities among others. Saccharomyces cerevisiae also inhibit the mycotoxin producing fungi and cause the degradation of poisonous cyanogenic glycosides and produces tissues degrading enzymes such as cellulose and pectinase. The volume of ethanol produced during fermentation is dependent on the strains of yeast used. For instance, the total alcohol (ethanol and methanol) produced from orange juice fermentation was $3.19 \% \mathrm{w} / \mathrm{v}$ with $S$. cerevisiae var. ellipsoideus and $6.80 \%$ w/v with $S$. carlsbergensis (Okunowo and Osuntoki 2007). During the production of sugarcane beverage called cachaca in Brazil, S. cerevisiae produced no methanol while contaminating yeasts (Pichia silvicola and P. anomala) produced $0.5 \%$ methanol (Dato et al. 2005). Stringini et al. (2009) studied yeast diversity during tapping and fermentation of oil palm wine from Cameroon and found S. cerevisiae, Saccharomyces ludwigii, Schizosaccharomyces bailli, Candida parapsilosis, Pichia fermentans, Hanseniaspora uvarum and Candida fermentati in addition to lactic acid bacteria and acetic acid bacteria. Literature abounds on the microbiology of traditionally fermented beverages. Karamoko et al. (2012) isolated yeasts, mould and bacteria including Bacillus, Brevibacterium, Micrococcus and Escherichia coli. Rokusu and Nwisienyi (1980) isolated lactic acid bacteria (Lactobacillus, Streptococcus and Leuconostoc) and Acetic acid bacteria (Acetobacter and Aerobacter). Stringini et al. (2009) using molecular techniques reported the diversity of yeasts involved in palm wine fermentation including S. cerevisiae and other yeast such as Candida parapsilosis, C. fermentati and Pichia fermentans. Similarly, the microbiology of other traditionally fermented alcoholic beverages and foods have been well documented (Ogbadu et al. 1997; Muyanja et al. 2003; Namuguraya and Muyanja 2009; Quattara et al. 2015; Koffi-Marcellin et al. 2009; Ashmaig et al. 2009; Eze et al. 2011).

Since traditional fermentation occur via spontaneous inoculation from the substrate and processing equipment (Ohimain et al. 2012; Jespersen 2003), hence mixed cultures usually carry out the fermentation. Therefore, contaminating microbes including other yeasts, fungi and bacteria could result in the production of several other products including methanol. And because methanol has a lower boiling point $\left(65^{\circ} \mathrm{C}\right)$ than ethanol $\left(78^{\circ} \mathrm{C}\right)$, it could be further concentrated in the beverage during distillation. Though, there are some disadvantages of mixed culture fermentation, the use of mixed culture in ethanol production will offer the advantage of production at low cost since a large range of substrates may be metabolized into ethanol. Moreover, the high cost associated with operations of process plants with pure cultures could be drastically minimized when mixed cultures are used.
As previously stated, mixed fermentation could result in the production of diverse products. Even pure culture fermentation can result in the production of diverse products depending on the operating conditions. Hence, beverages produced via spontaneous fermentation by mixed culture could produce greater variety of products. Table 2 listed some volatile congeners produced in selected alcoholic beverages beside methanol. Some of these compounds are also very poisonous e.g. ethyl carbamate and some are even carcinogenic (Lachenmeier et al. 2009, 2011; Testino et al. 2014; Testino and Borro 2010). Annan et al. (2003) listed 64 volatile compounds produced during the mixed culture fermentation of Ghanaian maize dough consisting of 20 alcohols, 22 carbonyls, 11 esters, 7 acids, 3 phenolic compounds and a furan.

\section{Recommendations and the way forward}

Paine and Davan (2001) reported that low concentrations of methanol occur naturally in most alcoholic beverages without causing any harm. According to WHO (2014), methanol concentration of 6-27 mg/l in beer and $10-220 \mathrm{mg} / \mathrm{l}$ in spirits are not harmful. Paine and Davan (2001) reported that the daily safe dose of methanol in an adult is $2 \mathrm{~g}$ and a toxic dose of $8 \mathrm{~g}$ as against the EU general limit for naturally occurring methanol of $10 \mathrm{~g}$ methanol/ethanol, which is equivalent to $0.4 \%(\mathrm{v} / \mathrm{v})$ methanol at $40 \%$ ethanol. Czech Republic permitted safe limit for methanol in spirits is $12 \mathrm{~g} / \mathrm{l}$ of pure ethanol (Vaskova 2013). Note that EU Methanol limit is variable (0.2-1.5 \%) depending on the type of beverage and feedstock used for fermentation. Some countries have regulatory limits of methanol in alcoholic beverages (Table 3). This regulatory control should be encouraged rather than outright ban.

Microbiological control of the process could also be used to prevent methanol formation in fermented beverages. For instance, pure culture inoculation using commercial yeast as opposed to spontaneous inoculation by wild yeasts should be practiced. The traditional fermentation processes could also be scaled-up using well characterized and purified starter culture. For instance, starter cultures have been successfully used to produce pito, a traditionally fermented alcoholic beverage produced from maize or sorghum (Orji et al. 2003). Adequate equipment with process controls should be used for fermentation and distillation as opposed to rudimentary equipment lacking controls, which are currently used. For instance, sterilization/boiling at temperatures higher than $80{ }^{\circ} \mathrm{C}$ could prevent the production of methanol (Chaiyasut et al. 2013; Amaral et al. 2005). Moreover, standard microbiological process controls and working under aseptic conditions could control contaminating wild yeasts in the fermentation process. Jespersen (2003) 
Table 2 Some volatile congeners in alcoholic beverages

\begin{tabular}{|c|c|c|c|}
\hline Congener & Concentration & Beverages & References \\
\hline \multirow[t]{5}{*}{ 1-butanol } & ND to 35 mg/l & Agrave & Leon-Rodriquez et al. (2008) \\
\hline & 8 to 74 mg/l & Plum wine & Jung et al. (2010) \\
\hline & 4.5 to $12 \mathrm{mg} / 100 \mathrm{ml}$ & Plum brandy & Kostik et al. (2014) \\
\hline & 1.0 to $5.2 \mathrm{mg} / 100 \mathrm{ml}$ & Grape brandy & Kostik et al. (2014) \\
\hline & ND to $9.8 \mathrm{mg} / \mathrm{l}$ & Raki & Gueven (2013) \\
\hline \multirow[t]{5}{*}{ 2-butanol } & ND to $59 \mathrm{mg} / \mathrm{l}$ & Agrave & Leon-Rodriquez et al. (2008) \\
\hline & 309 to 1092 mg/l & Plum wine & Jung et al. (2010) \\
\hline & 14.5 to $55 \mathrm{mg} / 100 \mathrm{ml}$ & Plum brandy & Kostik et al. (2014) \\
\hline & 1.5 to $110.5 \mathrm{mg} / 100 \mathrm{ml}$ & Grape brandy & Kostik et al. (2014) \\
\hline & ND to $18.39 \mathrm{mg} / \mathrm{l}$ & Raki & Gueven (2013) \\
\hline \multirow[t]{5}{*}{ 1-propanol } & ND to 708 mg/l & Agrave & Leon-Rodriquez et al. (2008) \\
\hline & 76 to $1141 \mathrm{mg} / \mathrm{l}$ & Plum wine & Jung et al. (2010) \\
\hline & 22 to $305 \mathrm{mg} / 100 \mathrm{ml}$ & Plum brandy & Kostik et al. (2014) \\
\hline & 4.1 to $90.5 \mathrm{mg} / 100 \mathrm{ml}$ & Grape brandy & Kostik et al. (2014) \\
\hline & ND to 727 mg/l & Raki & Gueven (2013) \\
\hline \multirow[t]{2}{*}{ 2-propanol } & 12.2 to $26.5 \mathrm{mg} / 100 \mathrm{ml}$ & Plum brandy & Kostik et al. (2014) \\
\hline & 7 to $26.5 \mathrm{mg} / 100 \mathrm{ml}$ & Grape brandy & Kostik et al. (2014) \\
\hline Acetic acid & ND to $1192 \mathrm{mg} / \mathrm{l}$ & Agrave & Leon-Rodriquez et al. (2008) \\
\hline Acetone & 25 to $40 \mathrm{mg} / \mathrm{l}$ & Plum wine & Jung et al. (2010) \\
\hline Aldehyde & ND to $67.3 \mathrm{mg} / \mathrm{l}$ & Raki & Gueven (2013) \\
\hline \multirow[t]{5}{*}{ Ethyl acetate } & ND to $30.19 \mathrm{mg} / \mathrm{l}$ & Wines and spirits & Osobamiro (2013) \\
\hline & 100 to $474 \mathrm{mg} / \mathrm{l}$ & Agrave & Leon-Rodriquez et al. (2008) \\
\hline & 48 to $454 \mathrm{mg} / 100 \mathrm{ml}$ & Plum brandy & Kostik et al. (2014) \\
\hline & 5.2 to $255 \mathrm{mg} / 100 \mathrm{ml}$ & Grape brandy & Kostik et al. (2014) \\
\hline & 12.8 to $292 \mathrm{mg} / \mathrm{l}$ & Raki & Gueven (2013) \\
\hline \multirow[t]{3}{*}{ Ethyl carbamate } & 378 to $421 \mu \mathrm{g} / \mathrm{kg}$ & Yellow rice wine & Wu et al. (2014) \\
\hline & ND to $40.65 \mathrm{mg} / \mathrm{l}$ & Wines and spirits & Osobamiro (2013) \\
\hline & $<0.15 \mathrm{mg} / \mathrm{l}$ & Agrave & Lachenmeier et al. (2009) \\
\hline \multirow[t]{2}{*}{ Higher alcohol ${ }^{\mathrm{a}}$} & 267 to 2007 mg/l & Agrave & Leon-Rodriquez et al. (2008) \\
\hline & ND to 2275 mg/l & Raki & Gueven (2013) \\
\hline
\end{tabular}

${ }^{a}$ Higher alcohol are alcohols with molecular weight higher than ethanol i.e. alcohol that has more than 2 carbon; ND not detected

Table 3 Regulatory limits of methanol in beverages

\begin{tabular}{|c|c|c|}
\hline Country & Maximum methanol value ${ }^{a}$ & Reference \\
\hline Brazil & $0.5 \%(0.5 \mathrm{ml} / 100 \mathrm{ml})$ & Mendonca et al. (2011) \\
\hline Thailand & $0.024 \%(240 \mathrm{mg} / \mathrm{l})$ & Chaiyasut et al. (2013) \\
\hline Australia/New Zealand & $0.8 \%(8 \mathrm{~g} / \mathrm{l})$ & Chaiyasut et al. (2013) \\
\hline$E U^{b}$ & $\begin{array}{l}200 \mathrm{~g} / \mathrm{hl}(0.2 \% \text { for wine \& brandy, } 1000 \mathrm{~g} / \mathrm{hl}(1 \%) \text { for } \\
\text { grape marc spirit and fruit spirit, } 1500 \mathrm{~g} / \mathrm{hl}(1.5 \%) \text { for } \\
\text { fruit marc spirit }\end{array}$ & European Community (2008) \\
\hline USA & $0.1 \%$ & FDA (Federal Food, Drug and Cosmetic Act 21 USC 34 (a)(2)(C) \\
\hline Vietnam & $0.3 \%$ & Socialist Republic of Vietnam (2010) \\
\hline Nigeria & $0.0005 \%$ (5 mg/l) & NAFDAC (2005) \\
\hline
\end{tabular}

a Concentration of methanol in ethanol

b EU limits for methanol in alcoholic beverages is variable depending on the type of beverage and the feedstock used for fermentation 
also recommended improved process control of fermentation and product characterization including the use of purified starter cultures with appropriate technology.

Another microbiological method for the control of methanol in fermented beverages, is the use of methylotrophic yeast such as Pichia methanolica (Nakagawa et al. 2005) and Candida boidinii (Nakagawa et al. 2000) which have the capacity of utilizing pectin or methyl ester moiety of pectin and methanol, thus preventing the accumulation of methanol in fermented products. Finally, instead of an outright ban on traditional fermentation, because of methanol contamination, the mixed alcohol (ethanol and methanol) could be further processed and used as biofuel. Literature abounds on the use of methanol and ethanol as biofuels (Kamboj and Karimi 2014; Iliev 2015; Shayan et al. 2011).

\section{Conclusions}

Incidences of methanol contamination in traditional beverages are increasing globally and have caused death in many counties including Nigeria, India and Indonesia. It is generally believed that unscrupulous vendors deliberately spike the beverages with methanol in order to increase the alcohol content. This review observed that methanol production in traditional fermented beverages can be linked to the activities of pectinase producing yeast, fungi and bacteria. Microbes producing pectin methyl esterase are able to produce methanol from fruits/juices containing pectin. Under traditional/ informal fermentation, alcoholic beverages produced by mixed microbial consortium could probably lead to the production of mixed alcohols containing methanol and other volatile congeners. The study concluded by suggesting that contaminated alcoholic beverages be converted for fuel use rather than out rightly banning the agelong traditional alcohol fermentation. Regulatory limits for methanol in fermented beverages should be strictly enforced. It is also suggested that pure cultures should be used for alcohol fermentation under aseptic conditions as opposed to spontaneous fermentation by mixed contaminating microbes.

\footnotetext{
Acknowledgements

The author wishes to thank Mr. Sylvester Izah of the Niger Delta University for the editorial work, the anonymous reviewers and editors for their useful comments and suggestions and the management of Springerplus for waiving the article processing fees.
}

\section{Authors' contributions}

EIO carried out the entire work including liteture review and report writing. The author have read and approved the final manuscript.

\section{Competing interests}

The author declare that they have no competing interests.
Ethical approval

This article does not contain any studies with human participants or animals performed by author.

\section{Funding}

This study received no external funding as it was solely funded by the author.

Received: 19 April 2016 Accepted: 11 September 2016

Published online: 20 September 2016

\section{References}

Aiyeloja AA, Oladele AT, Tumulo A (2014) Potentials of Raphia hookeri whine in livelihood and sustenance among rural and urban populations in Nigeria. Int J Soc Behav Educ Econ Manage Eng 8(7):2316-2323

Aka S, Camara F, Nanga YZ, Loukou YG, Dje KM (2008) Evaluation of organic acids and sugar contents during the production of "Tchapalo", a traditional Sorghum beer in Cote D'Ivoire. J Food Technol 6(5):189-195

Amaral SHD, Assis SAD, Oliviera OM (2005) Partial purification and characterization of pectin methyl esterase from orange (Citrus sinensis). J Food Biochem 29:367-380

Annah NT, Poll L, Sefa-Dedeh Plahar WA, Jakobsen M (2003) Volatile compounds produced by Lactobacillus fermentum, Saccharomyces cerevisiae, Candida krusei in single starter culture fermentations of Ghanaian maize dough. J Appl Microbiol 94:462-474

Ashmaig A, Hasan A, Gaali EE (2009) Identification of lactic acid bacteria isolated from traditional Sudanese fermented camel's milk (Gariss). Afr J Microbiol Res 3(8):451-457

Azadnia P, Khan NAH (2009) Identification of lactic acid bacteria isolated from traditional drinking yoghurt in tribes of fars province. Iran J Vet Res 10(3):235-240

Chaiyasut C, Jantavong S, Kruatama C, Peerajan S, Sirilum S, Shank L (2013) Factors affecting methanol content of fermented plant beverage containing Morinda citrifolia. Afr J Biotechnol 12(27):4356-4363

Dato MCF, Junior JMP, Mutton MJR (2005) Analysis of the secondary compounds produced by Saccharomyces cerevisiae and wild yeast strains during the production of "cachaca". Braz J Microbiol 36:70-74

Dorokhov YL, Shindyapina AV, Sheshukova EV, Komarova TV (2015) Metabolic methanol: molecular pathways and physiological roles. Physiol Rev 95:603-644

European Community (2008). Regulation (EC) No 110/2008 of the European Parliament and of the council on the definition, presentation, labelling and the protection of geographical indications of spirit drinks and repealing Council Regulation (EEC) No. 1576/89. Official Journal of the European Union. L 39/16. 13.2.2008

Eze VC, Eleke OI, Omeh YS (2011) Microbiological and nutritional qualities of burukutu sold in mammy market Abakpa, Enugu state. Nigeria. Am J Food Nutr 1(3):141-146

Ezeronye OU, Legras JL (2009) Genetic analysis of Saccharomyces cerevisiae strains isolated from palm wine in eastern Nigeria Comparison with other African strains. J Appl Microbiol 106:1569-1578

Fernandez-Gonzalez M, Ubeda JF, Cordero-Otero RR (2005) Engineering of an oenological Saccharomyces cerevisiae strain with pectinolytic activity and its effect on wine. Int J Food Microbiol 102:173-183

Gainvors A, Frezier V, Lemarequisier H, Aigle M, Belarbi A (1994a) Detection of polygalacturonase, pectin-lyase and pectin-esterase activities in a Sacchromyces cerevisae strain. Yeast 10:1311-1319

Gainvors A, Karam N, Lequart C, Belarbi A (1994b) Use of Saccharomyces cerevisiae for the clarification of fruit juices. Biotechnol Lett 16:1329-1334

Guerra JB, Araujo RAC, Pataro C, Franco GR, Moreira ESA, Mendonca-Hagler Rosa CA (2001) Genetic diversity of Saccharomyces cerevisiae strains during the $24 \mathrm{~h}$ fermentative cycle for the production of the artisanal Brazilian cachaca. Lett Appl Microbiol 33:106-111

Gueven A (2013) Chemical fingerprints of Raki: a traditional distilled alcoholic beverage. J Inst Brew 119:126-132

Hayford AE, Jespersen L (1999) Characterization of saccharomyces cerevisiae strains from spontaneously fermented maize dough by profiles of assimilation, chromosome polymorphism, PCR and MAL. J Appl Microbiol 86:284-294 
Iliev S (2015) A comparison of ethanol and methanol blending with gasoline using a I-D engine model. Procedia Eng 100:1013-1022

Islam MN, Ferdous N, Nesha K, Rasker JJ (2014) Alcoholic beverages in Bangladesh-how much we know? Family Med Med Sci Res 3(2):1. doi:10.4172/2327-4972.1000123

Iwuoha Cl, Eke OS (1996) Nigerian indigenous fermented foods: their traditional process operation, inherent problems, improvements and current status. Food Res Int 29(5-6):527-540

Jespersen L (2003) Occurrence and taxonomic characteristics of strains of Saccharomyces cerevisiae predominant in African indigenous fermented foods and beverages. FEMS Yeast Res 3:191-200

Joshi VK, Sharma S, Devi MP (2009) Influence of different yeast strains on fermentation behavior, physio-chemical and sensory qualities of plum wine. Nat prod Radiance 8(4):445-451

Jung A, Jung H, Auwarter V, Pollak S, Farr AM, Hecser L, Schiopu A (2010) Volatile congeners in alcoholic beverages: analysis and Forensic significance. Rom J Leg Med 18:265-270

Kamboj SK, Karimi MN (2014) A comparison of performance parameters with use of ethanol and methanol fuel blends, and engine speed of SI engine. Thermal Energ Power Eng 3(1):198-205

Karamoko D, Djeni NT, N'guessan KF, Bouatenin KMJ, Dje KM (2012) The biochemical and microbiological quality of palm wine samples produced at different periods during tapping and changes which occurred during their storage. Food Control 26:504-511

Koffi-Marcellin DJE, Solange AKA, Zinzendorf NY, Celestin YAOK, Guillaume LY (2009) Predominant lactic acid bacteria involved in the spontaneous fermentation step of Tchapalo process, a traditional Sorghum Beer of Cote D' ivoire. Res J Biol Sci 4(7):789-795

Kostik V, Gjorgeska B, Angelovska B, Kovacevska I (2014) Determination of some volatile compounds in fruit spirit produced from grapes (Vitis vinifera L.) and plums (Prunus domestica L.) cultivars. Sci J Anal Chem 2(4):41-46

Kuhle AVD, Jesperen L, Glover RLK, Diawara B, Jakobsen M (2001) Identification and characterization of Saccharomyces cerevisiae strains isolated from West African sorghum beer. Yeast 18:1069-1079

Lachenmeier DW, Kanteres F, Kuballa T, Lopez MG, Rehm J (2009) Ethyl carbamate in alcoholic beverages from Mexico (tequila, mezcal, bacanora, Sotol) and Guatemala (Cuxa): market survey and risk assessment. Int J Environ Res Public Health 6:349-360

Lachenmeier DW, Schoeberl K, Kanteres F, Kuballa T, Sohnius EM, Rehm J (2011) Is contaminated unrecorded alcohol a health problem in the European Union? A review of existing and methodological outline for future studies. Addiction 106(suppl 1):20-30

Leon-Rodriguez AD, Escalante-Minakata P, Jimenez-Garcia MI, OrdonezAcevedo LG, Flores JLF, Rosa APBDL (2008) Characterization of volatile compounds from ethnic agrave alcoholic beverages by gas chromatography-mass spectrometry. Food Technol Biotechnol 46(4):448-455

Mendonca AR, Geocze CA, Maria SC, Souza OE (2011) Potential application of Saccharomyces cerevisiae strains for the fermentation of banana pulp. Afr J Biotechnol 10(18):3608-3615

Methanol Institute (2013) Adulterated alcohol poisoning: issue summary. Methanol Institute

Micheli F (2001) Pectin methylesterases: cell wall enzymes with important roles in plant physiology. Trends Plant Sci 6:414-419

Muyanja CM, Narvhus JA, Treimo J, Langsrud T (2003) Isolation, characterization and identification of lactic acid bacteria from bushera: a Ugandan traditional fermented beverage. Int J Food Microbiol 80(3):201-210

NAFDAC (2005) National agency for food and drug administration and control act 1993 (as amended). Spirit drinks regulations 2005

Nakagawa T, Miyaji T, Yurimoto H, Sakai Y, Kato N, Tomizuka N (2000) A methylIrophic pathway participates in pectin utilization by Candida boidinii. Appl Environ Microbiol 66(10):4253-4257

Nakagawa T, Yamada K, Fujimura S, Ito T, Miyaji T, Tomizuka N (2005) Pectin utilization by the methylotrophic yeast, Pichia methanolica. Microbiol 151:2047-2052

Namuguraya BS, Muyanja CMBK (2009) Traditional processing, microbiological, physiochemical and sensory characteristics of KWETE, a Ugandan fermented maize based beverage. Afr J Food Agric Nutr Dev 9(4):1046-1059

Naumov Gl, Naumova ES, Aigle M, Masneuf I, Belarbi A (2001) Genetic reidentification of the pectinolytic yeast strain SCPP as Saccharomyces cerevisiae var. Uvarum. Appl Microbiol Biotechnol 55:108-111
Obahiagbon FI (2009) A review of the origin, morphology, cultivation, economic products, health and physiological implications of raphia palm. Afr J Food Sci 3(13):447-453

Obahiagbon Fl, Osagie AU (2007) Sugar and macrominerals composition of sap produced by Raphia hookeri palms. Afr J Biotechnol 6(6):744-750

Oduah AA, Ohimain El (2015) Ethnobotany of raffia palm (Raphia hookeri), productivity assessment and characterization of raffia palm oil from the Niger Delta, Nigeria. Res J Phytomed 1(1):33-38

Ogbadu L, Momo-Jimoh A, Ameh JB (1997) Short communication: heat treatment and chemical preservatives and their effects on the keeping quality of burukutu beer. World J Microbiol Biotechnol 13:131-132

Ogbulie TE, Ogbulie JN, Njoku HO (2007) Comparative study on the microbiology and shelf life stability of palm wine from Elaeis guineensis and Raphia hookeri obtained from Okigwe. Nigeria. Afr J Biotechnol Res 6(7):914-922

Ohimain El, Tuwon PE, Ayibaebi EA (2012) Traditional fermentation and distillation of raffia palm sap for the production of bioethanol in Bayelsa State, Nigeria. J Technol Innov Renew Energ 1(2):131-141

Ohimain El, Osai Inyang IR, Gu A (2015) The effects of raffia palm mesocarp on haematological parameters of Clarias gariepinus, a common Niger Delta Wetland Fish. Ann Res Rev Biol 8(1):1-7

Okunowo WO, Osuntoki AA (2007) Quantification of alcohols in orange wine fermented by four strains of yeast. Afr J Biochem Res 1:95-100

Okunowo WO, Okotore RO, Osuntoki AA (2005) The alcoholic fermentative efficacy of Indigenous yeast strains of different origin on orange juice. Afr J Biotechnol 4(1):1290-1296

Ollivier B, Garcia J-L (1990) Thermophilic methanogenesis from pectin by a mixed defined bacterial culture. Curr Microbiol 20:77-81

Orji MU, Mbata TI, Aniche GN, Ahonkhai I (2003) The use of starter cultures t produce 'pito', a Nigerian fermented alcoholic beverage. World J Microbiol Biotechnol 19:733-736

Osobamiro T (2013) Analysis of some contaminants commonly found in alcoholic beverages. Am-Eur J Sci Res 8(1):53-56

Paine A, Davan AD (2001) Defining a tolerable concentration of methanol in alcoholic drinks. Hum Exp Toxicol 20(11):563-568

Pataro C, Guerra JB, Petrillo-Peixoto ML, Mendonca-Hagler LC, Linardi VR, Rosa CA (2000) Yeast communities and genetic polymorphism of Saccharomyces cerevisiae strains associated with artisanal fermentation in Brazil. J Appl Microbiol 89:24-31

Prade RA, Zhan D, Ayoubi P, Mort AJ (1999) Pectins, pectinases and plantmicrobe interactions. In: Biotechnology and genetic engineering reviews, vol. 16. Intercept Limited, UK, pp 361-391

Quattara CAT, Somda MK, Moyen R, Traore AS (2015) Isolation and identification of lactic acid and non-acid lactic bacteria from "degue" of western African traditional fermented millet-based food. Afr J Microbiol Res 9(36):2001-2005

Rokosu AA, Nwisienyi JJ (1980) Variation in the component of palm wine during fermentation. Enzyme Microbe Technol 2(1):63-65

Schink B, Zeikus JG (1980) Microbial methanol formation: a major end product of pectin metabolism. Curr Microbiol 4:387-389

Sefa-Dedeh S, Sanni Al, Tetteh G, Sakyi-Dawson E (1999) Yeasts in the traditional brewing of pito in Ghana. World J Microbiol Biotechnol 15:593-597

Shale K, Mukamugema J, Leus RJ, Venter P, Mokoena KK (2013) Characterisation of selected volatile organic compounds in Rwandan indigenous beer 'Urwagwa' by dynamic headspace gas chromatography-mass spectrometry. Afr J Biotechnol 12(20):2990-2996

Shayan SB, Seyedpour SM, Ommi F, Moosavy SH, Alizadeh M (2011) Impact of methanol-gasoline fuel belnds on the performance and exhaust emission of SI engine. Int J Automotive Eng 1(3):219-226

Shindyapina AV, Petrunia IV, Komarova TV, Sheshukova EV, Kosorukov VS, Kiryanov Gl, Dorokhov YL (2014) Dietary methanol regulates human gene activity. PLOS ONE 9:e102837

Sieiro C, Garcia-Fragna B, Lopez-Seijas J (2012) Microbial pectic enzymes in the food and wine industry. In: Valdez B (ed) Food industrial processes- methods and equipment. Intech, pp 201-218

Siragusa RJ, Cerda JJ, Baig MM, Burgin CW, Robbins FL (1988) Methanol production from the degradation of pectin by human colonic bacteria. Am J Clin Nutr 47:848-851

Socialist Republic of Vietnam (2010) National technical regulation of food safety for alcoholic beverages. Socialist Republic of Vietnam 
Stringini M, Comitini F, Taccari M, Ciani M (2009) Yeast diversity during tapping and fermentation of palm wine from Cameroon. Food Microbiol 26:415-420

Testino G, Borro P (2010) Alcohol and gastrointestinal oncology. World J Gastrointest 2(8):322-325

Testino G, Leone S, Borro P (2014) Alcohol and hepatocellular carcinoma: a review and a point of view. World J Gastroenterol 20(43):15943-15954
Vaskova H (2013) Quantitative evaluation of methanol content in beverages based on raman spectral data. Mathematics Computers Biology Biomed informatics No volume: 81-85

WHO (2014) Methanol poisoning outbreaks. Information note. World Health Organization, Geneva

Wu P, Cai C, Yang D, Wang L, Zhou Y, Shen X, Ma B, Tan J (2014) Changes of ethyl carbamate in yellow rice wine during shelf-life and formation in simulated ethanol and urea solutions. J Food Nutr Res 2(12):872-875

\section{Submit your manuscript to a SpringerOpen ${ }^{\odot}$ journal and benefit from:}

- Convenient online submission

\section{- Rigorous peer review}

- Immediate publication on acceptance

- Open access: articles freely available online

- High visibility within the field

- Retaining the copyright to your article 